\title{
Challenges of teaching humanities in innovative educational environment
}

\author{
Aza D. Ioseliani ${ }^{1 *}$, Esther Heletz ${ }^{2}$, and Polina P. Rostovtseva ${ }^{3}$ \\ ${ }^{1}$ Financial University under the Government of the Russian Federation, Department of Humanities, \\ Moscow, Russia \\ ${ }^{2}$ Corporate Central Business DrivenTM, Software Development, San Francisco, California, USA \\ ${ }^{3}$ Financial University under the Government of the Russian Federation, Department of English for \\ Professional Communication, Moscow, Russia
}

\begin{abstract}
This article analyzes the issues of implementation of innovations and respective methodology of teaching humanities in universities. The aim of this article is to reveal challenges related with implementation and use of advanced innovative methods of teaching humanities in universities. This work substantiates the concept that modern processes occurring in education are direct consequence of complicated and deep transformations in culture, economy, policy of the World. Adaptation of life to wide-scale transformations is impossible without holistic comprehension of motives, trends and prospects of further social development, including education. The novelty of the work is in development of certain theoretic models of education development, which is rapidly moving away from the differentiation and fragmentation of scientific disciplines, modules and is concentrated on their integration. Another novelty in the existing paradigm of education can be presented by targeting of potential not just on distance methods but on creation of innovative education systems based, for instance, on technologies of virtual reality (VR). This work proves that in VR the educational components or prototypes can be presented by such units as virtual laboratory (workshop), lecture spaces, displaying of considered entities, network educational establishments.
\end{abstract}

Keywords: methodology, humanities, innovations, virtual reality.

\section{Introduction}

Formation of efficient and innovative educational environment aided by modern models and technologies of education is a strategically important target of reformation and updating of modern science and education in the Russian Federation.

Organization of educational process in university should be oriented at rational application and expansion of the use of modern aids and education technologies widely provided by information engineering. The main purpose of universities should be formation of creative, educated, and professionally mobile person, who could orient in practical activity and be adapted to continuous changes in social and cultural area [1].

\footnotetext{
* Corresponding author: aioseliani@,fa.ru
} 
Nowadays selection of new methods and forms of teaching in the system of higher education is sufficiently active. This is related with formulation of the problem of gradual transition of teaching into interactive mode.

The research aim is to reveal challenges related with innovative approaches to teaching humanities in universities.

The research targets are as follows:

1) to determine modern trends of running methodological transformations in education;

2) to study positive and negative points of implementation of innovative methods into methodology of teaching humanities in universities;

3 ) to analyze the significance of joint use of conventional and innovative technologies in teaching humanities.

\section{Methods}

This research was based on the following research methods: general scientific analysis, which allowed to study general methodology of teaching humanities; social cultural method, which allowed to reveal social cultural foundations of modern education; hypothetical and deductive method, due to which it was substantiated that the future of education directly depended on implementation and application of modern innovative methodology of education.

\section{Discussion}

The theoretical base of this article is comprised of the works of the following Russian and foreign authors: A. Yu. Galushkina [1], E.V. Komolova and M.A. Ishutina [2], Tahani Z. Aldahdouh, Petri Nokelainen and Vesa Korhonen [3], T.M. Makhamatov, T.T. Makhamatov and S.T. Makhamatova [4], T. N. Seregina [5], T.E. Sivolap [6], B.T. Reinitz [7], and others, who analyzed methodological, scientific, and social cultural aspects of teaching humanities.

\section{Results}

The novelty of the work is in development of certain logical structures and theoretical models of education development. Practical significance of the work is that the experimental results can be useful in creation of innovative methodology of teaching humanities, as well as in development of educational programs of various specialties, manuals and courses on social and humanities.

Modern level of development of post-industrial culture [1] and its contradictions indicate that the existing social movements are transitional and will be matured during more than one decade.

Many modern researchers underline peculiar significance of the use of new innovative technologies during education and advanced training of professional skills of young people $[3,8]$.

The education system has the historic mission of preservation and transmission of cultural and civilizational heritage. Such mission in its essence is quite conservative; however, each new generation makes it possible to change the vector and dynamics of development of this mission. The classical type and models of education, which are still inherent to education of post-Soviet period, facilitate development of other technologies on the basis of interdisciplinary approach. On this basis, it would be reasonable to direct all potential and experience at development of innovative structures of education, which could be based, say, on technologies of virtual reality. 
Virtual reality (VR), that changed life of nearly all people and humanity in whole [4: 817818], is considered as imaginary, new mediated world, created by hi-tech. This world, though illusory, is transferred to a human via the senses (e.i. vision, hearing). The VR is based on human-machine interface, due to which the effect of 3D environment is created. In the VR, a person has the opportunity to interact online with virtual objects, including people [9].

In modern world, in education there appeared great demand for wide-scale implementation and application of the Internet and VR. In this regard, scientific studies are carried out devoted to their features and opportunities for education, science, social sphere, culture, modern world, information community [10-13].

And what can give VR to education, how can it be used and what innovative means or spaces can be created for performing scientific, cultural, and educational projects?

In this regard, the opportunities are expansive, for instance, virtual lecture classes can be created, virtual laboratories, visualized museums, various workshops, conference halls, etc. This is especially important today during the pandemic and restrictions required for protection against it.

Opportunities and resources of VR can be applied in all types of education, full-time, part-time and distance education using tele- and video-conferences.

Modern experts argue about efficiency and reasonability of applying VR in teaching humanities. This is attributed to the fact that education is based on systematic understanding of the integrity of real world (including VR), and its results are mainly evaluated by software [9] and multispectral diagnostic systems in virtual educational environment $[11,14,15]$. Application of such systems is reasonable during knowledge evaluation of exact disciplines. For instance, in mathematics it is important that students obtain one and the same true answer and numerical result; however, in humanitarian sciences, unified for everybody answers are in fact impossible. This is caused by specificity of humanities, which is expressed in that the search for correct answer goes from logical and theoretical statements to inferences, which allow individual interpretations of problems [2].

In the issue of implementation of innovations into methods of teaching humanities, the issue of teacher's place and role in education process is very important. In the new virtual educational system, the role of teacher changes, he is transformed from bearer and transmitter of knowledge into tutor or supervisor [9].

As is known, the previous educational paradigm presented knowledge to students in already developed form; however, it should be mentioned that teaching humanities never took place without translation of personal experience of teacher, teaching was always based on uniqueness of teacher's opinion about the subject and study material, teacher's professional attitude. Such understanding of the issue confirms that a teacher during education is not just a transmitter of the meaning of study material but also an interpreter of the knowledge to be learned by students [6].

We believe that humanitarian sciences are rich and flexible resource of development of creative thinking of students. There is a popular and valid opinion that the education is mainly interaction between students and teachers in the frames of high human relations [2]. The validity of this point of view is based on psychological constituent of teaching humanities.

\section{Conclusion}

In conclusion it should be mentioned that during formation of foundations of teaching humanities under the existing conditions, several issues should be considered: difficulty levels of learning process, discipline itself and specific studied material, as well as opportunities of implementation and use of hi-tech in educational process. Specific language of humanitarian sciences, reflecting the subject of thinking, exerts great influence on psychological aspects of knowledge perception by students, creating potentials for personal 
development, growth and self-improvement. Herewith, it should be taken into account that the language of humanitarian sciences itself is under the influence of national and religious values and norms; hence, while selecting methods and forms of education, it is necessary to account for their spiritual and worldview features [5, 10].

\section{References}

1. A.Yu. Galushkina, Mezhdunarodnyy Studencheskiy Nauchnyy Vestnik [International Student Scientific Bulletin], 2, (2018) Accessed on: November 23, 2020. [Online]. Available: https://eduherald.ru/ru/article/view?id=18093

2. E.V. Komolova, M. A. Ishutina, Problemy Obespecheniya Bezopasnosti pri Likvidatsii Posledstviy Chrezvychaynykh Situatsiy [Problems of Ensuring Safety in the Elimination Consequences of Emergency Situations], 1, 467-470 (2014)

3. T.Z. Aldahdouh, P. Nokelainen, V. Korhonen, SAGE Open, January-March, 1-20 (2020). https://doi.org/10.1177/2158244019899441

4. T.M. Makhamatov, T.T. Makhamatov, S.T. Makhamatova, Lecture Notes in Networks and Systems. Scientific and Technical Revolution: Yesterday, Today and Tomorrow, 129, 816-825 (2020)

5. T. Seregina, S. Zubanova, V. Druzhinin, G. Sagivaleeva, Space and Culture, India, 7(3), 243-253 (2019)

6. T.E. Sivolap, Trudy Sankt-Peterburgskogo Gosudarstvennogo Instituta Kul'tury [Proceedings of the St. Petersburg State Institute of Culture], 1, 408-413 (2013)

7. B.T. Reinitz, Trends and Technologies: Cloud. EDUCAUSE Center for Analysis and Research. USA (2017). Accessed on: December 23, 2020. [Online]. Available: https://library.educause.edu/resources/2017/5/2017-trends-and-technologies-cloud

8. S.M. Al-Daihani, J.S. Al-Qallaf, S.A. AlSaheeb, Global Knowledge, Memory and Communication, 67(6/7), 412-424 (2018). https://doi.org/10.1108/GKMC-11-20170091

9. A.M. Novikov, Postindustrialnoye obrazovaniye [Postindustrial Education] (Egves, Moscow, 2008)

10. A.D. Ioseliani, Studies in Computational Intelligence, 826, 447-453 (2019)

11. S. Manca, M. Ranieri, Education and Information Technologies, 22(2), 605-622 (2017). https://doi.org/10.1007/s10639-015-9429-x

12. Y. Wang, G. Meiselwitz, Social media and higher education: a literature review, in G. Meiselwitz (Ed.), Social computing and social media, 96-105 (Springer, Los Angeles, 2015)

13. S. Hamid, J. Waycott, S. Kurnia, S. Chang, Internet and Higher Education, 26, 1-9 (2015). https://doi.org/10.1016/j.iheduc.2015.02.004

14. R.A. Singatulin, E.A. Grishchenko, Primeneniye mul'tispektral'nykh diagnosticheskikh sistem v virtual'noy obrazovatel 'noy srede [Application of multispectral diagnostic systems in a virtual educational environment], in Informatsionnyye tekhnologii v obespechenii novogo kachestva vysshego obrazovaniya [Information technology in providing a new quality of higher education], Book 2, 246-249 (ICPKPS, Moscow, 2010)

15. A. Manca, A. Whitworth, The Journal of Social Media in Society, 7(1), 151-183, (2018) 